\title{
Ricardian Equivalence, the Italian Fiscal Tradition and Western Australia's Government Net Debt
}

\author{
Michael McLure ${ }^{1}$
}

This paper uses the discussion within the Italian fiscal tradition on the supposed Ricardian equivalence between debt and taxation to give context to the Western Australian (WA) Government's growing net debt from the late phase of the 'millennium boom'. It is suggested that WA's experience, in which growth in net debt has been driven significantly by growth in general government expenses, accords best with Pareto's main reason for rejecting Ricardian equivalence. The WA Government did have a strategy to maintain structural fiscal balance over the long term, but the targets or rules associated with that strategy were abandoned and replaced by weaker rules. It is argued that, if those rules were more 'constitutional' in character, then the WA Government's net debt would not have blown out in the manner that it did.

\section{Introduction}

The start of the 'millennium boom' can be dated as 2002-03 (Grafton 2012). The Western Australian (WA) Government was a major beneficiary of that boom, with the value of the state's export of iron ore growing hectically in response to China's booming demand for steel. Notwithstanding this, WA Government public finances have seen total government 'net debt' grow from $\$ 4$ billion (or 27 per cent of total government operating revenue) in 2002-03 to \$27 billion in 2015-16 (or 62 per cent of total government operating revenue); and the 2016-17 Government Mid-year Financial Projections Statement predicts that WA's total public-sector net debt will reach $\$ 39.7$ billion by 30 June 2020 .

\footnotetext{
1 University of Western Australia, michael.mclure@uwa.edu.au. The author would like to thank Jill Trinh, for her contributions as my research assistant, the referees and especially William Coleman, for their very helpful comments.
} 
The primary purpose of this paper is to interpret the growth of the Government of Western Australia's net debt from 2004-05 onwards with reference to the Italian fiscal tradition. Particular attention is given to the treatment of the 'Ricardian equivalence' between debt and taxation by Antonio De Viti de Marco (1992), under his hedonistic approach; Benvenuto Griziotti (1992), under his political approach; and Vilfredo Pareto (1975), under his sociological approach. A secondary purpose of the paper is to reflect on the primary reason for the ineffectiveness of the WA Government's budgetary framework and its associated fiscal targets from 2006-07 onwards.

Some readers may wonder about the relevance of using the views of Italian economists, formulated approximately 100 years ago, about a theory advanced by Ricardo 200 years ago, to comment on contemporary public finances in WA. But the approach is justified on three main grounds. First, following the twentiethcentury revival in the economics of Ricardian equivalence, which dates back to Barro (1974, 1979) and Buchanan (1976), there is still some contemporary relevance to macroeconomic analysis that is linked to Ricardian equivalence. Second, Public Choice is a major intellectual framework for contemporary investigations and the Italian fiscal tradition was a significant inspiration for many of the leading Public Choice scholars. For example, James Buchanan spent the 1955-56 academic year in Italy on a Fulbright scholarship, during which time he undertook research into the Italian fiscal tradition that culminated in his celebrated paper " La Scienza delle Finanze": The Italian Tradition in Fiscal Theory' (1960). Third, the Italian literature on Ricardian equivalence has some implications for modern fiscal arrangements, even though neither 'welfare-oriented' nor 'Public Choice-oriented' studies of public finance depend on Ricardian equivalence per se.

The next section of the paper provides a general overview of the three main approaches within the Italian fiscal tradition and discusses their respective treatment of Ricardian equivalence. That is followed by a review of WA Government net debt from 2004-05 onwards and a discussion of the character of that debt with reference to the three main approaches within the Italian fiscal tradition. The final substantive section provides a reflection of the ineffectiveness of the WA Government's fiscal targets and points to a Public Choice mechanism that may have reduced the extent of, or even prevented, WA's debt problem. The study concludes that the WA Government's experience with public debt over the period considered is generally consistent with Pareto's rejection of Ricardian equivalence because debt is fundamentally a device that governments employ to win public acceptance of larger government. It is also concluded that if budgetary sustainability-without the re-emergence of ongoing fiscal imbalances_-is to return to WA, targets associated with the state's fiscal strategy will need to acquire greater 'constitutional' character. 


\section{The Italian fiscal tradition}

Three distinct approaches to the theories of public finance developed within the Italian tradition between the 1880s and 1920s: the hedonistic approach, the political approach and the sociological approach. ${ }^{2}$ The hedonistic approach is associated with the early work of Pantaleoni (1967) and the theories of De Viti de Marco (1888) and Ugo Mazzola (1890). Pantaleoni (1967) had posited that parliament can seek to maximise the sum of total utility across society by estimating the scale of marginal utilities of various expenditures (assessed in terms of the average intelligence of parliamentary representatives), and arranging expenditure priorities in decreasing order of their marginal utilities net of the taxation required to fund each respective activity. De Viti de Marco (1888) and Mazzola (1890) recognised that benefits of some services are 'irreducible' and, from that, a deep and highly analytical discussion emerged on 'public needs'. ${ }^{3}$ The political approach is mainly associated with Giovanni Montemartini (1967), Amilcare Puviani (1903), and with Benvenuto Griziotti (1992) for his work on Ricardian equivalence. These authors were critical of the hedonistic approach for ignoring, or underemphasising, the motivations of the ruling class when acting politically, and their use of the coercive force of law to spread the costs associated with particular benefits, which are enjoyed by subsets of society, across the entire society. The sociological approach is primarily a synthesis of Pareto's economic and sociological thinking and was largely undertaken by Gino Borgatta (1920 [2007]) and Guido Sensini (1932), who complemented the economics of public finance with the sociology of public finance to account for the influence of 'non-logical' (but not 'illogical') actions on fiscal decisions. The resulting 'fiscal sociology' focuses on 'fiscal redistribution' and the ways that the non-logical elements within fiscal decisions impact on the balance between 'consent', given willingly within a society by individuals who are governed, and 'force' imposed by those who govern upon the governed.

The particular issue considered within the Italian fiscal tradition that is of greatest relevance to this paper is the positions taken by De Viti de Marco, Griziotti and Pareto on the Ricardian equivalence between taxation and debt.

In his classic study On the Principles of Political Economy and Taxation (1951 [1817]), and in his essay on the 'Funding System' (1951 [1820]), David Ricardo considered, among other things, the question of war finance. Specifically, he reflected on whether 'extraordinary' expenditure on war from tax increases was equivalent to funding that same expenditure from debt (i.e. through the issue of interest-bearing government bonds). In that case extraordinary tax funding has the same present value as the postponed-progressive payment scheme (debt funding) because taxes

\footnotetext{
2 See Mauro Fasiani (1932-33).

3 Amedeo Fossati (2003) has pointed out De Viti de Marco's position on this issue is more general than that of Emile Sax's pioneering work on public goods as he considers both 'material' and 'immaterial' goods.
} 
will need to be higher in the future to service debt. The central fiscal issue at stake was, of course, whether it is possible to shift some of the economic burden of a war to future generations by funding that war from debt rather than taxation. Ricardian equivalence suggests that the tax burden cannot be shifted from the current generation and onto subsequent generations when individuals are rational and forward-looking.

In nineteenth-century England, the primary context of Ricardian equivalence remained as a question within the specialised topic of war finance, with John Stuart Mill taking the matter further. But today, of course, the Ricardian equivalence proposition has acquired a stronger macroeconomic dimension, with Barro defining it as the proposition that 'shifts in debt and tax finance for a given amount of public expenditure would have no first order effect on the real interest rate, volume of investment, etc.' (1979: 940). But between Ricardo's war finance discussions of 1817 and 1820 and Barro's macroeconomic discussion of debt and taxation in the 1970s, the question of Ricardian equivalence was also subjected to thorough investigation by members of the Italian fiscal tradition. This episode has been captured well by James Buchanan in Public Principles of Public Debt: A Defense and Restatement (1958) and by Stefano Toso in 'The Italian School of Public Finance at the Turn of the Century and the Ricardian Equivalence Theorem' (1992).

When De Viti de Marco was a leader of a 'hedonistic' stream of Italian public finance, he set about rectifying what he saw as shortcomings of Ricardo's treatment of the equivalence between debt and taxation. In 'La Pressione Tributaria dell'Imposta e del Prestito' (1992), De Viti de Marco attempted to demonstrate that individual owners of capital and individual wage earners act rationally in regard to intertemporal decisions to the extent that they do discount expected tax flows and they do so to make provision for future tax obligations. In that case, he regarded the burden of debt as the same as the burden of tax for both owners of capital and workers, as the burden becomes effective from the moment that the extraordinary expenditure is introduced.

Griziotti (1992), however, did not accept De Viti de Marco's demonstration of Ricardian equivalence. He pointed out that some sets of low-income workers would be unable to pay an extraordinary tax but they may be able to contribute to a lesser ongoing tax imposed to meet the servicing costs of debt. And, importantly, this takes place within a political context that involves conflict and sectional interests and, within that context, the assumption that rates of return equalise among the various factors of product is entirely unrealistic. The net result is a rejection of Ricardian equivalence. As Buchanan (1958: 118) observed:

Griziotti's whole point is that the two financing forms [debt and taxation] themselves must involve different distributions of the burden among income classes, and because of this, among separate time periods. 
Griziotti also used the question of Ricardian equivalence to distance himself from the hedonistic approach of the Italian tradition and align himself loosely with the 'political' approach. ${ }^{4}$ In his words (1992: 81):

for some time now I have found myself increasingly at odds with the intellectual line of De Viti de Marco and the majority of academics who interpret the question of public finance using economic criteria. In my opinion, public finance criteria [are] essentially political in nature.

Griziotti was justifiably proud of his paper on Ricardian equivalence and sent a copy to his former teacher Pareto, who was, however, completely underwhelmed (McLure 2007). Pareto rejected the usefulness of any discussion of Ricardian equivalence because it distracted from one of the first-order issues in public finance, which concerns influences that alter people's willingness to accommodate increasingly large governments. In that regard, Pareto saw debt as a device for extracting a greater value of resources from the community: 'Debt is a way of making the population accept that which would not be acceptable through taxes' (Pareto 1975: 989). In recognising that debt is an important mechanism through which the 'governed' are persuaded to accept larger government, Pareto and the Italian Paretians set about developing a fiscal sociology that focused on the scope for, and the patterns of, fiscally directed redistribution, and the role played by 'non-logical' rationalisations that are developed in support of prevailing or alternative redistributions implemented via fiscal means.

The literature on Ricardian equivalence is formally concerned with the circumstances in which there will be an economic equivalence between debt and the introduction of extraordinary non-distorting taxation when raising a given sum. This contrasts with the 'modern' welfare analysis, which emphasises the deadweight losses from different types of taxes and/or intergenerational spillover benefits from spending on education and human capital; and considers how 'tax smoothing', subject to the intertemporal budget constraint, can reduce deadweight losses over time (Reitschuler 2010; Li and Zhang 2015). Under that approach, tax smoothing and 'optimal deficits' contribute to efficient public finances. And that modern welfare framework contrasts with the competing Public Choice approach, which contends that the size of government is not independent of the degree of the efficiency of taxation. The rule of thumb is that the higher the deadweight loss of taxation (i.e. the more inefficient the taxation system is) the smaller the government. Conversely, the introduction of efficient tax smoothing and 'optimal deficits' would act to increase public spending and lead to bigger governments.

4 Griziotti went on to occupy a distinct space in the Italian fiscal tradition that placed great emphasis on the jurisprudential dimensions to fiscal activities. 
The De Vito de Marco discussion of Ricardian equivalence broadly lines up with the modern welfare-oriented approach to public finance, ${ }^{5}$ not because of the modern approach maintains an equivalence tax and debt (it does not) but because the relationship between taxes and public debt is fundamentally concerned with the efficiency of public supply, not with the effect of such efficient supply on the size of government. Conversely, Pareto's position on tax and debt broadly lines up more closely with the Public Choice approach because, in a dynamic sense, the size of government is linked to the balance of taxation and debt used to fund current expenses. Griziotti provides highly qualified support for Ricardian equivalence in principle, but, in practice, the intrusion of political objectives on fiscal decisions prevents the achievement of that equivalence. As such, his view represents an intermediate position that accommodates some elements from both the welfareoriented approach to public finance and Public Choice.

\section{The character of Western Australian Government net debt}

The effects of the boom on the WA Government budget were evident from the early 2000s onwards, but a full understanding of its effect did not emerge until the middle of the first decade of the millennium. The 2006-07 WA Budget was particularly upbeat and included a special discussion of 'Issues in Public Sector Finances-Building on the Boom-Utilising the Surplus' (Government of Western Australia 2007: 42). The upshot of this was that the government planned to use its Consolidated Fund surpluses from the boom to reduce the debt burden of government by allocating surplus funds to repay MetroRail borrowings and to reduce the need for subsequent MetroRail borrowings. Notably, general government net debt had actually become 'negative' in 2003-04 and budget forward estimates indicated that that would remain so until 2009-10 (the final year of the forward estimated).

But the optimism of the 2006-07 Budget did not endure as fiscal pressure emerged from 2008-09 onwards. By 2010-11, WA general government net debt had become 'positive' again (for the first time in eight years) and has subsequently risen progressively each year, reaching $\$ 14$ billion in 2015-16. The WA general government's share of total WA Government net debt rose progressively from 2 per cent, in 2010-11, to 50 per cent, in 2015-16.

5 It should, however, be stressed that this conclusion is confined to De Viti de Marco's assessment of Ricardian equivalence. His broader body of work is much admired by many Public Choice economists, especially Giuseppe Eusepi and Richard Wagner (2013). 


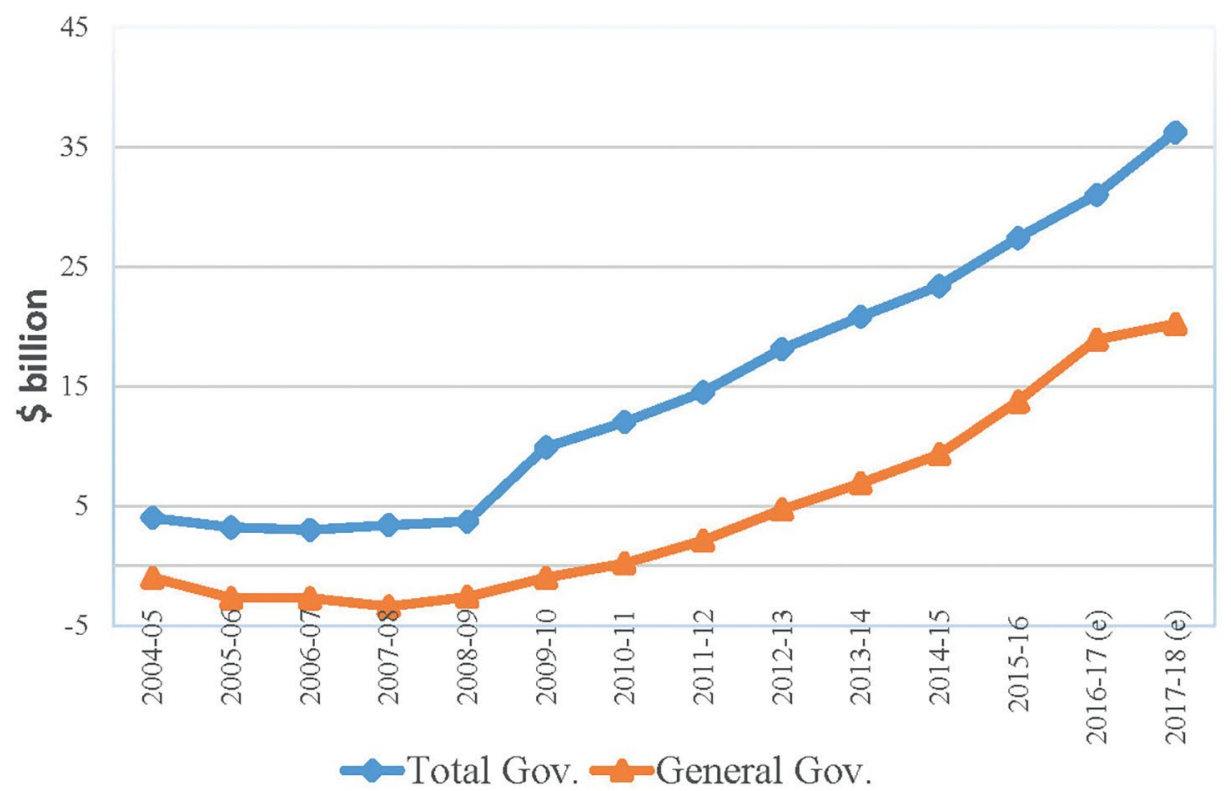

Figure 1: WA Government: \$billion net debt

Source: WA Treasury, Annual Reports of State Finances

In visual terms, Figure 1 shows that the slopes of the respective trajectories for net debt in the general government sector and in total WA Government are similar from 2009-10 onwards. The level of net debt associated with the non-general government sector (e.g. public business corporations) has risen modestly from $\$ 11$ billion, in 2009-10, to $\$ 14$ billion, in 2015-16. But in WA's general government sector, net debt has risen from 'negative' $\$ 1$ billion, in 2009-10, to 'positive' $\$ 14$ billion, in 2014-15. Clearly, then, WA's total government debt has been driven by the activities of the general government.

Of course, a significant part of the WA net debt story in more recent years has been linked to the progressive reduction in the state's share of the goods and service tax (GST). This is because the Commonwealth Grants Commission application of the fiscal equalisation principle acts to reduce a state's GST share when its revenueraising capacity rises relative to that of the other states and, in the case of WA, the iron ore boom increased the state's overall revenue-raising capacity. There are, however, lags in the Commission's assessment process. For example, the GST share applied in 2016-17 was agreed in 2015-16 and was based on a three-year assessment period from 2012-12 to 2014-15 inclusive. The WA Treasury collect current data in an attempt to forecast likely future changes to its GST share; however, because of genuine uncertainty, the resulting estimates are very proximate. But even that provides a forward-looking government with some capacity to plan. 
But the fiscal problem that WA has faced has more elements than just the GST. The general impact of the millennium boom on a whole range of tax bases and the impact of the subsequent easing and termination of that boom on tax bases are also relevant considerations. And, most importantly, as the trajectory of general government net debt ultimately concerns the balance between revenue growth and expense growth, growth in expenses must also figure prominently in any analysis of public debt. In the case of the WA Government, the fiscal problem can be formulated in the following terms. How did growth in general government expenses alter in the face of the following three challenges to WA Government revenue: (i) the certainty that, after a lag, Commonwealth Grants Commission's formula would reduce WA's share of the GST due to its increase in revenue-raising capacity related to the boom; (ii) the certainty that the State revenue growth in general would slow as the boom dissipated and ultimately terminated; and (iii) the highly probable expectation that State's reduction in GST - evident from lags in the Commonwealth Grants Commission's assessments - would come at the very moment when the iron ore boom was dissipating and growth in State revenues bases were slowing? Unfortunately, the government did not alter its expenses, with growth in general government expenses fully matched by growth in general government revenue during the boom years until 2012, so a gap between expenditure and revenue opened and widened between 2013 and 2016, when general government expenditure exceeded revenue, from the end of the boom until its aftermath.

This growth in general government expenses is largely associated with wage expenditure, with the average annual growth rate of general government wages in WA being 8.2 per cent between 2005-06 and 2013-14 (calculated from data in Government of Western Australia 2016: 47). That is, the nominal wages bill for the general government sector in WA doubled over that period. The average annual growth in WA general government expenses over the 10 years to 2013-14 was of a similar order of magnitude, growing at 7.9 per cent (Government of Western Australia 2016: 45).

Figure 2 also reveals that the growth of WA Government debt was not dominated by total public sector capital works, which is relatively flat (fluctuating between $\$ 5$ billion and $\$ 7$ billion per year) in comparison to the curve for general government expenses. The millennium boom in WA temporarily expanded revenue-raising capacity and contemporaneously fuelled general government wages growth, which permanently increased the public sector wages bill. The GST distribution formula compounded this problem, with the end result being increased pressure on WA Government net debt. 


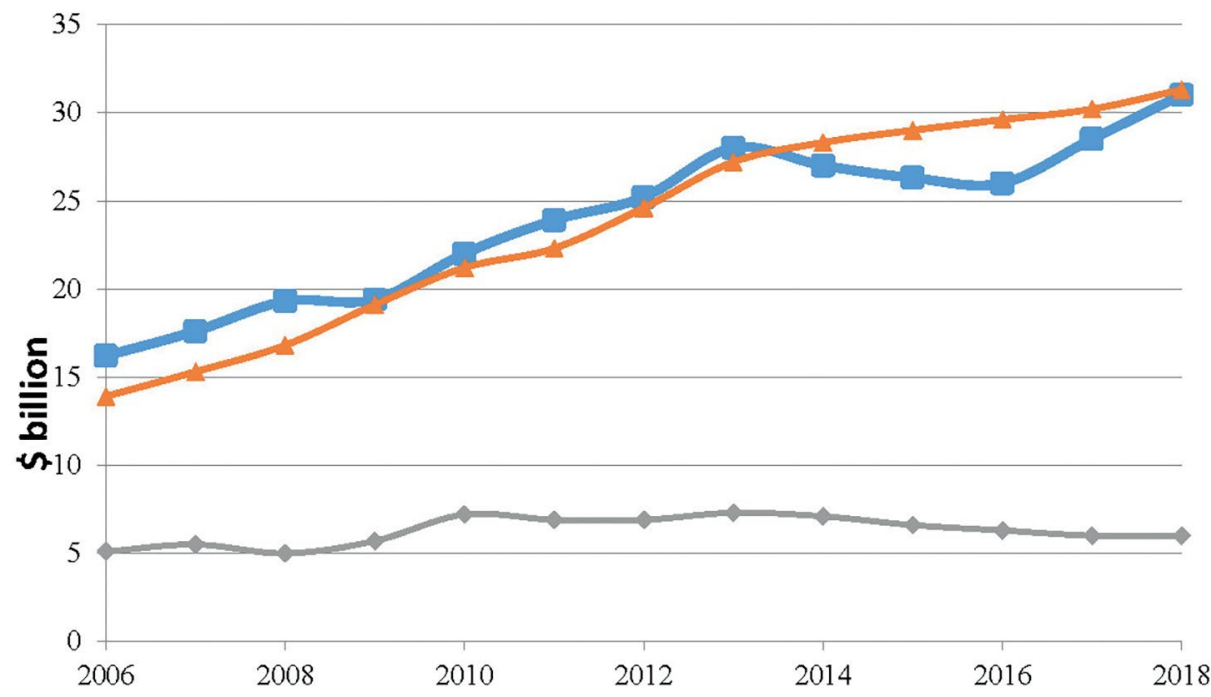

-WA: GG Revenue (\$ Billion)

$\multimap$ WA: GG Expense (\$ Billion)

$\neg$ WA: Total Public Sector Capial Works (\$ Billion)

Figure 2: WA Government finances

Source: WA Treasury, Annual Reports of State Finances

If De Viti de Marco's hedonistic framing of Ricardian equivalents held, in a positive sense, the WA Government's revenue windfall from the temporary increase in revenue-raising capacity would have had no impact on government spending. Indeed, the temporary increase would have been offset by a temporary reduction in debt and/or in tax rates because Ricardian equivalence is implicitly predicated on a 'given' expenditure being funded. As this temporary revenue increase was not attributable to an increase in tax rate or royalty rates, the conclusion is much the same under the welfare-oriented approach to efficient taxation and debt. That is, the demand for public services would be unchanged by the windfall and intertemporal efficiency would see net debt reduced as optimal deficits become an optimal surplus during the years of the temporary boom.

If Griziotti's political framing of Ricardian equivalence held, there would be an imperfect attempt to offset rising revenue-raising capacity by a partial mix of lower debt with lower taxes rates, although the distribution of that benefit among individuals would, as a result of the political dimension to fiscal activity, be influenced by class conflict and clashes between competing sectional interests. This is also much the same as what one would expect if the government applied the welfare-oriented 
approach to efficient taxes with intertemporal budget constraints, except part of the state's windfall from the boom would be deliberately redistributed to targeted subsets of interest groups in society.

If Pareto's rejection of Ricardian equivalence held, then the windfall from the temporary rise in revenue-raising capacity would be considered from the perspective of whether there is a long-term impact on the size of the state government. Pareto did not discuss the mechanism through which this would occur, but, by inference, the sequence would run as follows: the windfall would be spent by the government, rather than be returned to the community in tax cuts, and once the windfall has ended, the newly increased size of government would be maintained into the future by a combination of increased net debt, in the first instance, followed shortly thereafter by increases in tax and/or royalty rates as a 'responsible' government attempted to regain control of its 'net debt' problem.

The WA experience over the last 10 or 12 years shows that the increase in revenueraising capacity during, and immediately following, the boom was not significantly offset by tax reductions. Modest reductions in state taxation were introduced through extensions to exemption thresholds ${ }^{6}$ (although more significant reductions were made to land $\operatorname{tax}^{7}$ ), but not enough to noticeably slow the rate of revenue growth. The more important fact is that public expenses continued to grow. Consequently, debt appears to have become a way of extracting more from the taxpayers of Western Australia to, in large part, fund the growth of wages paid to government employees. This was partly in response to labour market pressures created by the millennium boom but largely due to a lack of willingness by the State government to constrain growth in its general government outlays. This experience is unequivocally better reflective of Pareto's view on debt and taxation than that of De Viti de Marco's hedonistic approach or, to a lesser extent, Griziotti's political approach.

\section{A public choice mechanism that may have prevented WA's debt problem}

The rationale for rules has been considered by Geoffrey Brennan and Buchanan (1985), and again by Buchanan (1987) in his acceptance speech for the Sveriges Riksbank Prize in Economic Sciences in Memory of Alfred Nobel, when he emphasised the importance of rules in public finance as part of a constitutional

\footnotetext{
6 For example, payroll tax exemption threshold was increased from $\$ 750,000$ to $\$ 800,000$ in 2014 , and transfer duty exemption thresholds for first home purchases were increased in 2004 and 2007 and then reduced in 2014.

$7 \quad$ With the land boom increasing residential land values greatly over the five years to 2008/09, tax-free thresholds were increased significantly over that period. In part, this reflected the politically sensitive nature of increases in residential land values, which, given bracket creep from the 'progressive' land tax scale, results in (voter) home owners receiving land tax bill increases that would grow much faster than land prices in the absence of such relief.
} 
contract established under the Rawlsian veil of ignorance. In such an abstract contractarian process, no one individual allows his or her personal self-interest to influence the setting of rules, which prescribe the boundaries and define the processes under which subsequent political action operates, because self-interest is veiled by one's ignorance of his or her material and other circumstances. But perhaps the key point for WA public finances is that fiscal targets may be effective when they enjoy a high degree of 'constitutional' character. That is, when fiscal rules have very wide (unanimous) support across the community, they are likely to endure over the long term and across all phases of a business cycle.

The WA Government certainly had, and continues to have, a budget framework that is defined with reference rules or strategic fiscal targets. The question emerges, then: did those fiscal targets have a high degree of constitutional status? To answer that question, it is first necessary to briefly consider the targets/rules that the WA Government adopted.

In Western Australia, fiscal targets are set under the authority of the Government Financial Responsibility Act 2000. In 2006-07, the WA Government's fiscal strategy was to ensure that the real net worth of the total government sector was maintained or increased. To that end, a number of fiscal targets were set. First, an operating surplus on the general government sector was required. Second, to maintain the state's tax competitiveness, WA tax revenue as a share of gross state product (GSP) was required to be below the average of other states. Finally, to maintain WA's AAA credit rating, the net debt to revenue ratio for the total non-financial public sector must be held at, or below, 47 per cent, and real per capita own-purpose expenses for the general government sector cannot increase.

However, these targets did not endure. They did not have 'constitutional' status in a Public Choice sense. The WA Government lost its AAA credit rating from Standard and Poor's (S\&P) in September 2013 (O'Connor 2015) and from Moody's in August 2014 (O'Connor 2016): in October 2015, S\&P put the WA Government's credit rating on negative watch (O'Connor 2015); and in February 2016, Moody's downgraded the state's credit rating from AA1 to AA2 (O'Connor 2016). The reason is evident from much of the discussion in this paper, but in specific reference to WA fiscal targets mentioned in the previous paragraph, the state's net debt to revenue ratio for the non-financial public sector rose progressively to reach 70 per cent in 2015-16 (compared to the target of 47 per cent considered necessary to retain the AAA credit rating), and real per capital own-purpose outlays rose by 13.5 per cent from $2006-07$ ( $\$ 7,400$ per person in $2015-16$ values) to 2015-16 (\$8,400 per person in $2015-16$ values).

How could such a violation of the government's fiscal targets have been permitted? Well, the government simply changed its fiscal targets. In the 2009-10 financial year, the requirement to keep the ratio of net debt to operating revenue in check 
was replaced by the requirement that shifted focus from the level of debt to the level of debt servicing costs (in a low interest rate environment): the budget goal was changed to 'maintain the ratio of total non-financial public-sector net interest costs as a share of revenue at or below 5\%' (Government of Western Australia 2010: 23). The tax competitiveness target was also watered down in response to WA's growth in revenue. ${ }^{8}$ In the 2015-16, the requirement to maintain and not exceed real per capita general government expenses was replaced, with the rather weak proposition that the general government sector expenses cannot grow faster than revenue growth. There is a weak link in the sense that, while it may help prevent a new structural imbalance in the budget emerging, it does nothing to reduce net debt incurred from WA's structural imbalances that emerged from the end of the millennium boom. Also, while the ratio of non-financial public-sector net debt to operating revenue had returned to the rank of fiscal targets, the target ratio itself had risen from 47 per cent to 55 per cent.

The key point here is that fiscal targets are in part designed to prevent the emergence of structural imbalances in budgets and they will only be successful when the set targets are enduring. They have to be suitable for both a booming economy-so governments don't waste boom revenue-making unsustainable increases in ongoing recurrent spending — and a slowing economy in recession—so governments don't lose control of growth in net debt. When targets are not met, that should be a sign to governments that they have to adjust spending, or revenue, and a sign to taxpayers that fiscal adjustments are pending. It is not, as WA's experience with net debt and credit ratings suggest, an indication that it is time to change the state's fiscal targets. If WA's fiscal targets of 2006-07 were more 'constitutional' in character and maintained on an ongoing basis, then the WA Government would have been forced to act to prevent its level of net debt from growing into the very significant problem that it is today.

\section{Conclusion}

The increase in WA's state debt over the last 10 or 12 years was not primarily driven by the activities of the government's enterprises or expenses incurred undertaking capital works. It is true that the recent increase in debt over the last four or five years is linked to fiscal equalisation, but that impact was not completely unexpected. And the impact of substantial increases in general government expenses, especially on wages, on WA's net debt cannot be ignored. When this issue is considered with reference to the Italian discussion of Ricardian equivalence, it appears that WA's experience matches closely with Pareto's main reason for his decision to ignore

8 It was changed from maintain WA tax revenue as a share of gross state product (GSP) at or below the average of other States to provide a fair and efficient taxation system that is competitive with other Australian States. 
Ricardian equivalence: in a positive sense, debt and tax are complements, not substitutes, as the combination of debt and taxes acts to enlarge the public sector. For the same reason, WA's experience is also at odds with the welfare-oriented approach to intertemporal budgets and tax smoothing. That is, WA debt was related more to increasing the size of the general government than it was to tax smoothing to diminish deadweight losses over time by running 'optimal deficits'. It is also concluded that the status of the targets associated with the fiscal framework rules must now be strengthened significantly - they must acquire a greater constitutional character so that they can endure across all phases of the full economic cycle-if the current debt problem is to be resolved in the long term while eliminating structural balances from future state budgets.

\section{References}

Barro, R. 1974. 'Are Government Bonds Net Wealth'. Journal of Political Economy 82 (6): 1095-1117. doi.org/10.1086/260266

1979. 'On the Determination of the Public Debt'. Journal of Political Economy 87 (5): 940-971. doi.org/10.1086/260807

Borgatta, G. 2007. 'The Scientific Study of Fiscal Phenomena'. In The Paretian School and Italian Fiscal Sociology, edited by M. McLure. Houndmills Basingstoke: Palgrave Macmillan. Originally published in 1920 as 'Lo Studio Scientifico dei Fenomeni Finanziari', Giornale degli Economisti e Rivista di Statistica 31 (60): 1-24, 81-116. doi.org/10.1057/9780230596269_13

Brennan, G. and Buchanan, J. 1985. The Reason of Rules. Cambridge: Cambridge University Press.

Buchanan, J. 1958. Public Principles of Public Debt: A Defense and Restatement, Homewood, Ill.: Richard D. Irwin.

— 1960. "'La Scienza delle Finanze”: The Italian Tradition in Fiscal Theory'. Fiscal Theory and Political Economy: Selected Essays, 24-74. Chapel Hill: University of North Carolina Press.

1976. 'Barro on the Ricardian Equivalence Theorem'. Journal of Political Economy 84 (2): 337-342. doi.org/10.1086/260436

1987. 'The Constitution of Economic Policy'. American Economic Review 77 (3): $243-250$.

De Viti de Marco, A. 1888. Il Carattere Teorico dell'Economia Finanziaria, Roma: Pasqualucci. 
1992. 'Fiscal Burden Arising from Taxation and Public Debt'. In Italian Economic Papers, edited by Luigi Pasinetti, 55-79. Oxford: Il Mulino and Oxford University Press. Originally published in 1893 as 'La Pressione Tributaria dell'Imposta e del Prestito', Giornale degli Economisti, Series 2, 6 (JanuaryMarch): 38-67, 216-231.

Eusepi, G. and Wagner, R. 2013. 'Tax Prices in a Democratic Polity: The Continuing Relevance of Antonio de Viti de Marco'. History of Political Economy 45 (1): 99-121. doi.org/10.1215/00182702-1965204

Fasiani, M. 1932-33. 'Der Gegenwärtige Stand der Reinen Theorie der Finanzwissenschaft in Italien'. Zeitschrift für Nationalökonomie 3 (5): pp. 651691. Translated into Italian in 1980 as 'La Teoria della Finanza Pubblica in Italia'. In Il Pensiero Economico Italiano 1850-1950, edited by Massimo Finoia, 117202. Bologna: Cappelli.

1949. 'Contributi di Pareto alla Scienza delle Finanze'. Giornale degli Economisti e Annali di Economia 8 (3-4): 129-173.

Fossati, A. 2003. 'Public Goods in the Italian Tradition'. In 'The Theory of Public Finance in Italy from the Origins to the 1940s', edited by Domenicantonio Fausto and Valeria De Bonis. Special issue. Pensiero Economico Italiano 11(1): 99-122. Pisa e Roma: Istituti ed itoriali e poligrafici internazionale.

Government of Western Australia 2007. 2006-07 Budget, Budget Paper No. 3. ourstatebudget.wa.gov.au/uploadedFiles/State_Budget/Budget_2006_-_2007/ bp3.pdf

— 2010. 2009-10 Annual Report on State Finances. www.treasury.wa.gov.au/ uploadedFiles/_Treasury/State_finances/arsf_200910.pdf?n=8666

2016. 2015-16 Budget, Budget Paper No. 3. static.ourstatebudget.wa.gov. au/15-16/2015-16-wa-state-budget_bp3.pdf

Grafton, Q. 2012. 'The Millennium Boom has Years to Run'. Australian Financial Review, 14 September. afr.com/markets/commodities/energy/ millennium-resources-boom-has-years-to-run-20120913-j1r7p

Griziotti, B. 1992. 'The Different Fiscal Burden of Public Debt and Extraordinary Taxation'. In Italian Economic Papers, edited by L.L. Pasinetti, 81-97. Oxford: Il Mulino and Oxford University Press. Originally published in 1917 as 'La Diversa Pressione Tributaria del Prestito e dell'Imposta'. Giornale degli Economisti e Rivista di Statistica 54 (3): 129-64, 313-34. 
Li, B. and Zhang, J. 2015. 'Efficient Education Subsidization and the Pay-AsYou-Use Principle'. Journal of Public Economics 129: 41-50. doi.org/10.1016/j. jpubeco.2015.07.002

Mazzola, U. 1890. I Dati Scientifici Della Finanza Pubblica, Roma: Ermanno Loescher.

McLure, M. 2007. The Paretian School and Italian Fiscal Sociology. Houndmills Basingstoke: Palgrave Macmillan. doi.org/10.1057/9780230596269

Montemartini, G. 1967. 'The Fundamental Principles of a Pure Public Finance'. In Classics in the Theory of Public Finance, edited by R.A. Musgrave and A.T. Peacock, 137-151. London: Macmillan. Originally published in 1900 as 'Le Basi Fondamentali di una Scienza Finanziaria Pura', Giornale degli Economisti II.

O'Connor, A. 2015. 'S\&P holds WA Credit Rating Steady with a Negative Outlook, Warns Government to Curtail Spending'. ABC News, posted 29 October. abc.net. $\mathrm{au} /$ news/2015-10-29/wa-credit-rating-steady-amid-spending-warning/6896618

— 2016. 'Moody's Downgrades WA Credit Rating as Commodities Prices Plunge; Fears of Debt Blowout'. ABC News, 8 February. abc.net.au/news/201602-08/moodys-downgrades-wa-credit-rating-aa1/7149196

Pantaleoni, M. 1967. 'Contribution to the Theory of the Distribution of Public Expenditure'. In Classics in the Theory of Public Finance, edited by R.A. Musgrave and A.T. Peacock. London: Macmillan. Originally published in 1883 as 'Contributo alla teoria della distribuzione della speza pubblica'. La Rassegna Italiana ottobre: 25-70. Reprinted in 1975 in Teoria della Finanza Publica, edited by F. Volpi. Milano: Angeli.

Pareto, V. 1975. 'A Benvenuto Griziotti', letter of 5 October 1917. In Correspondance, Vilfredo Pareto Euvres Complètes Tome 19-2, edited by G. Busino, 988-989. Genéve: Librairie Droz.

Puviani, A. 1903. Teoria dell'Illusione Finanziaria, Palermo: Sandron.

Reitschuler, G. 2010. 'Fiscal Policy and Optimal Taxation: Evidence from a Tax Smoothing Exercise'. Scottish Journal of Political Economy 57 (2): 238-252. doi. org/10.1111/j.1467-9485.2010.00515.x

Ricardo, D. 1951 [1817]. 'On the Principles of Political Economy and Taxation'. The Works and Correspondence of David Ricardo, Vol. 1, edited by P. Sraffa in collaboration with M. Dobb. Cambridge: Cambridge University Press for the Royal Economic Society. 
1951 [1820]. 'Funding System'. The Works and Correspondence of David Ricardo, Vol. 4 Pamphlets and Papers 1815-1823, edited by P. Sraffa in collaboration with M. Dobb. Cambridge: Cambridge University Press for the Royal Economic Society.

Sensini, G. 1932. 'La Finanza Sociologica'. Studi di Scienze Sociali (1): 232-252. Roma: Casa Libraria Editrice Italiana.

Toso, S. 1992. 'The Italian School of Public Finanace at the Turn of the Twentieth Century and the Ricardian Equivalence Theorem'. History of Political Economy 24 (4): 819-841. doi.org/10.1215/00182702-24-4-819 
This text is taken from Agenda, Volume 24-Number 1, 2017, edited by William Coleman, published 2017 by ANU Press, The Australian National University, Canberra, Australia.

dx.doi.org/10.22459/AG.24.01.2017.01 